\title{
Designing Interior Space for Drivers of Passenger Vehicle
}

\author{
VESNA K. SPASOJEVIĆ BRKIĆ, University of Belgrade, \\ Faculty of Mechanical Engineering, Belgrade \\ Review paper \\ UDC: 629.3 .042 \\ MILIVOJ M. KLARIN, University of Novi Sad, \\ Technical Faculty "Mihajlo Pupin” Zrenjanin \\ ALEKSANDAR Đ. BRKIĆ, University of Belgrade, \\ Faculty of Mechanical Engineering, Innovation Center, Belgrade \\ ZVONKO D. SAJFERT, University of Novi Sad, \\ Technical Faculty "Mihajlo Pupin” Zrenjanin
}

\begin{abstract}
The current study is a review of our previous papers with certain improvements, so it proves the hypothesis that passenger vehicles are still not sufficiently adapted to man in terms of ergonomics, especially from the aspect of interior space. In the ergonomic adjustment of passenger vehicles, the limits of anthropomeasures and technical limitations, are the most important. The methodology mainly uses operative investigations, and the "man-vehicle" system is optimized within existing limitations. Here, we also explain original methodology for modeling that space. The fact that there is a point " 0 " as the origin point of a coordinate system with $x, y$ and $z$ axes of the man-vehicle system, which can be considered to be more or less fixed, enabled us to determine more accurately the mechanical and mathematical codependence in this system. The paper also proves that the anthropomeasures of length have mechanical and mathematical functions which also determine the width, i.e. all three dimensions and provides the design of the space behind the windscreen glass, the position of the steering wheel and the position of the foot commands with space for feet and knees determined, as well as the total space which the driver occupies. It is proved that the floor-ceiling height of a vehicle is primarily affected by the anthropomeasures of seating height and lower leg, while width is affected by the anthropomeasures of lower and upper leg and only then by shoulder width, so that the interior space for the driver of a passenger vehicle is $1250 \mathrm{~mm}$ and the width for knees spread at seat level is $926 \mathrm{~mm}$ maximum.
\end{abstract}

Key words: passenger vehicle, driver, optimal interior space

\section{INTRODUCTION}

Adaptation of passenger car to man, depends on many factors in addition to a large extent by anthropometric adaptation, because it depends on the possible placement of man in the vehicle, and thus its comfort, safety and efficiency of vehicle operation. The driver in driving conditions is in a sitting position, which requires special adaptation of the visual angle and position of the human body the seat of the vehicle and position of the dimensions and form and place of commands and cursors. Man's body may be viewed as

Author's address: Vesna Spasojević Brkić, University of Belgrade, Faculty of Mechanical Engineering, Belgrade, Kraljice Marije 16

Paper received: 10.02.2014

Paper accepted: 05.03.2014. a kinematic chain or a series of mechanical conne ctions made up of bones and joints. The bones are surrounded by skeletal muscles that control the central nervous system providing the necessary force to overcome the Earth's serious and inertia and to carry out an assignment.

EU rules applied in the Regulations on the Safety of machinery [1] indicate that when the machine is used in the conditions of its envisaged use, discomfort, fatigue, and physical and mental effort facing controller machine must be reduced to a minimum, taking into account the principles of ergonomics, in particular that the operator can have different physical dimensions, strength and endurance; the operator has enough room to move parts of the body; to avoid speed controller determines the machine; to avoide monitoring machines that require a longer concentration operator; and knowing that the connection bet- 
ween the operator and the machine adjusts the expected characteristics of the operator.

The present study is review paper that sumarizes and continues our previous works [2, 3, 4, 5, 6] using the methodology of investigating the anthropomeasures of drivers of passenger vehicle. In studies $[2,4]$, the research was conducted from the standpoint of design mainly in the vertical plane $\mathrm{zx}$, while in the studies [5] and [6] it was done in the z-y plane. The importance of different planes analysis is also pointed in $[7,8,9,10]$.

Our aim was to place the greatest possible range of anthropomeasures within the limited height of interior space, from the small anthropomeasures of women to the large ones of men, i.e. from the $5^{\text {th }}$ percentile woman to the $95^{\text {th }}$ percentile man. In order to achieve this aim, we have designed a "man-vehicle" system using the fixed point " 0 ", where the driver's heel touches the vehicle floor under the foot accelerator command, an anthropometric driver mechanism flexible at the joints, and moved it within the limitations of the recommended angles of anthropomeasures defined in $[11,12,13]$ and shown on Figure 1 , so that all drivers have the same or similar visual angle. The accelerator command itself was optimally designed from the aspect of efficiency compared to many other alternatives according to [14].

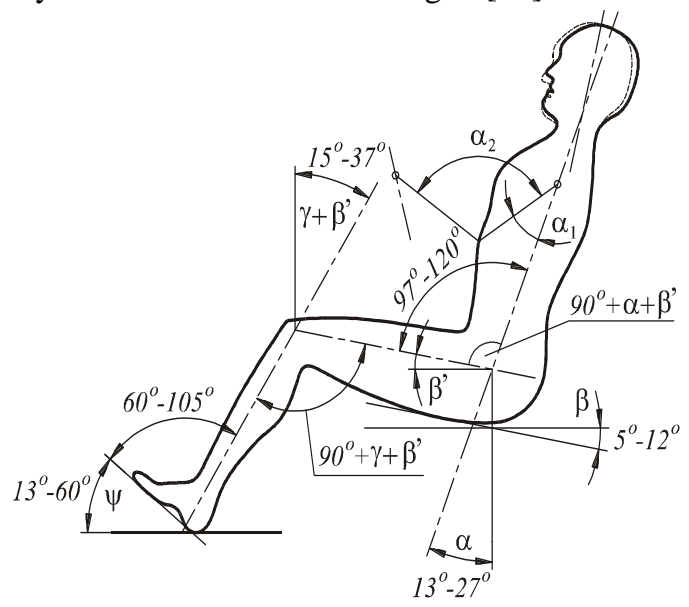

Figure 1 - Recommended angles of anthropomeasures in operating a passenger vehicle [5]

All drivers had to have the possibility of recommended ankle joint movements in order to operate the accelerator command, movements of an entire leg in order to operate the clutch and brake commands and also is needed to have an equal possibility to operate the steering wheel $[5,6]$. It was proved that the mechanism of anthropomeasures can be solved mathematically and shown graphically, and also computerprocessed, but that it can be presented by a simple model on a plane or in space, too, as our model has been used so far in [14] or according to [15], and which is shown in Figure 2.

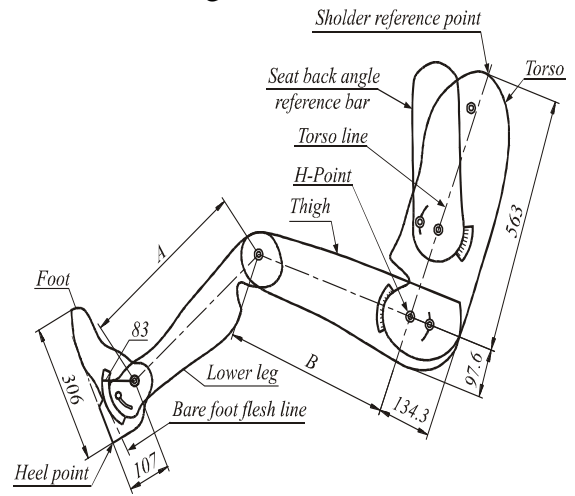

Figure 2 - Two dimensions template [6,14,15]

The basis for adapting the interior space of a passenger car to man is reduced to adjusting the seat to different anthropomeasures, where the solution for the given aims and limits lies in adjusting the seat in the front-back and up-down directions.

\section{ANTHROPOMETRICAL MEASUREMENTS IN SERBIA}

Anthropomeasures depend on sex, race, age, occupation of the participants, and on the anthropometric area where is observed. Anthropomeasures in any anthropometric area change and length has mainly increased since the middle ages whereas foot, shoulder and hip width have varied. Data collected in five periods of time are shown in Table 1

The monitoring is performed according to the methods of static anthropometry and in driving conditions, with clothes and footwear.

After a period of time, the number of anthropomeasures we had recorded was expanded, and instead of the initial seven measures in 1996, we last recorded 9 anthropomeasures in 2009. The latest sample is the best in many aspects, especially since it contains almost $20 \%$ of women, while in the 1976 sample there were only 75 women, or $3,94 \%$, of the total of 1900 tested.

The investigations so far in 1976, 1997, 2004 and 2007 were also used to design the universal methodology presented in our works $[2,5,16]$. Table 1 also presents out latest investigations from 2009, discussed in [6].

The samples in Table 1 are stratified, and the 1976 sample is stratified by the criteria of ethnicity, sex, age and occupation, whereas the samples from 1997, 2004 and 2007 are only stratified according to sex and age,. In all cases the stratification was successful. We used the same equipment for all measurements. 
Table 1. Data from investigations done in 1976, 1997, 2004, 2007 and 2009 [2, 5, 6, 16]

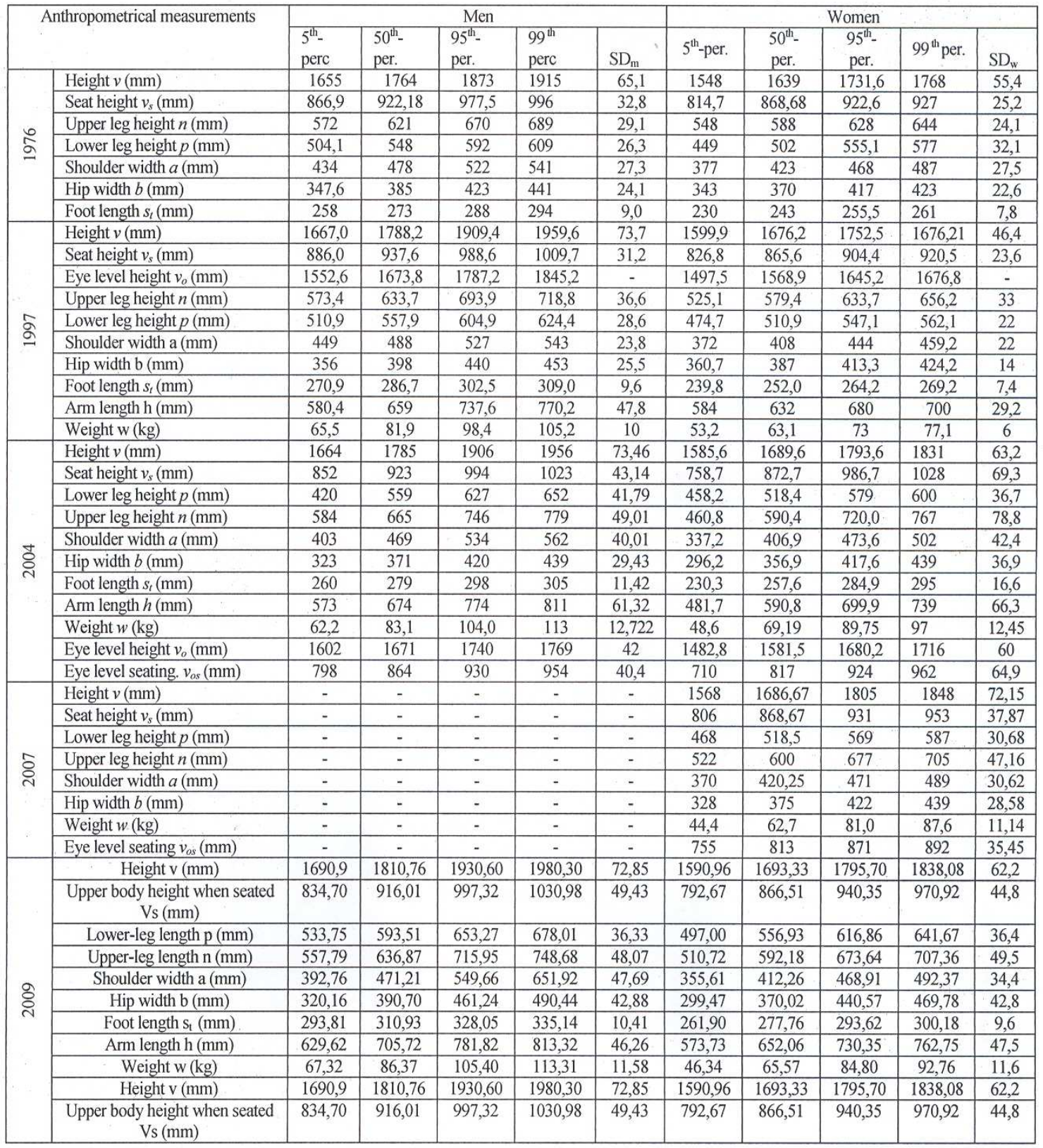

\section{INTERIOR SPACE IN Z-X PLANE}

In the 2008 paper [16], the optimal interior space of a vehicle in the $\mathrm{z}$-x plane was determined, as given in Figure 3. The Figure 3 indicates that the population range between the $5^{\text {th }}$ percentile woman and the $95^{\text {th }}$ percentile man is possible to accommodate within the car floor-ceiling dimensions of $1250 \mathrm{~mm}$. Horizontally, it is $1300 \mathrm{~mm}$ from the " 0 " point at the heel point of the $95^{\text {th }}$ percentile man to the back of the head point in model 2 in the Figure, whose seat height is $195 \mathrm{~mm}$ and backrest inclination $20 \mathrm{~mm}$. However, the driver cannot reach the fixed steering wheel. The solution is either to design an adjustable steering wheel or to move the driver forward to the sitting height of $250 \mathrm{~mm}$. The mentioned sitting height also enables the seating of the $95^{\text {th }}$ percentile man. The lower part of the space below the windscreen glass is determined by the sitting height of the $5^{\text {th }}$ percentile female driver. The horizontal distance from the foot is determined by the foot of the $95^{\text {th }}$ percentile male driver according to model 1, and equals approx. $230 \mathrm{~mm}$ at $160 \mathrm{~mm}$ height. Model 2 requires the space of approx $200 \mathrm{~mm}$ horizontally and $200 \mathrm{~mm}$ vertically, but wit- 
hout any supplementary space for the clearance of the entire foot movement.

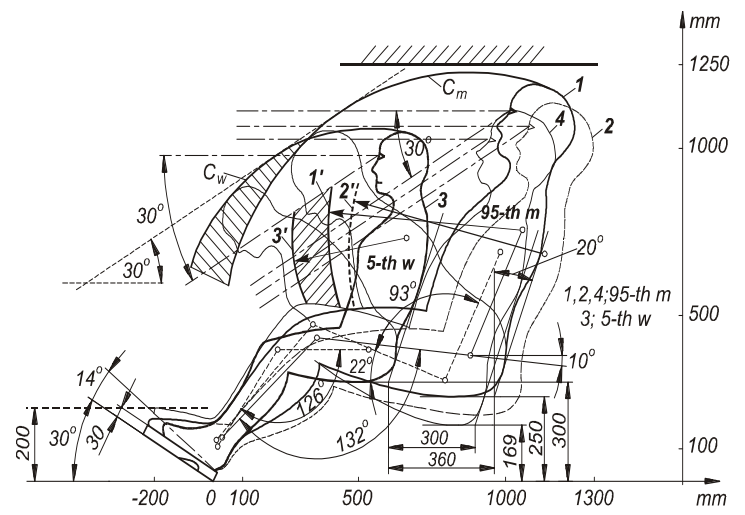

Figure 3 - The interior of a passenger vehicle for the seating of a driver between the $5^{\text {th }}$ percentile women and a $95^{\text {th }}$ percentile man [2]

We have thus determined this space in the first interaction, and only for operating the accelerator pedal. The position of feet and the shape of space for foot controls accommodation are equally determined by the dimensions of the upper leg and lower leg, thereby the angles between them and the dimensions of the feet. Some people have a small lower leg and large upper leg, and vice versa, therefore care should be taken of this as well. The same refers to both feet and lower legs. A higher but wider vehicle can have equal forehead surface, so the more adequate vehicle from the aspect of movement stability is the one which has greater width and consequently greater distance between wheels. A lower centre is also required which in turn also requires engines which would be lower in all other characteristics because not only the forehead surface would be smaller but the aerodynamics of the front part of the vehicle would be improved. The width of the passenger vehicle is also affected by the width of traffic lanes and the total width of the road which is intended for buses, lorries and special vehicles which are far larger and heavier, so in that respect the technical requirements for the width of passenger vehicle can be more easily met. Interior space must be considered with respect to the use of all three controls. The dimensions of space and controls will be estimated from the proposed origin of the coordinate system with three spatial axes. The position of the feet in operating the foot controls, and the dimensions and shape of the space for the accommodation of the fixed foot controls are also determined by the sitting height and the limitations on vehicle height due to air resistance, which should be as low as possible. The aim is also to have the whole vehicle as low as possible, since that is the requirement of technical limitations, namely that the forehead surface is as small as possible, because of the resistance of the air in the direction of movement of the car. The result from the requirement that the forehead surface should be as small as possible is that the floor-ceiling dimension is minimal too. The aerodynamics of the vehicle body, on the other hand, are also determined by its length. A higher but wider vehicle can have equal forehead surface, so a more appropriate vehicle from the aspect of movement stability is one which has greater width and consequently greater distance between wheels.

A lower centre is also required which in turn also requires engines which would be lower in all other characteristics because not only the forehead surface would be smaller but also the aerodynamics of the front part of the vehicle would be improved. The width of a passenger vehicle is also affected by the width of traffic lanes and the total width of the road which is intended for buses, lorries and special vehicles which are far larger and heavier, so in that respect the technical requirements for the width of passenger vehicles can be more easily met. The incline of the windscreen glass has a very important role in decreasing air resistance, and it is significant that a $30^{\circ}$ angle was determined by seating this range of drivers.

\section{INTERIOR SPACE IN Z-Y PLANE FOR ACCOMMODATION OF FOOT CONTROLS}

In our papers $[5,6]$ we have shown that for determining the optimal space for foot commands it is necessary to have a reference point " 0 " which determines both this space and the entire interior space of a passenger vehicle. Works that also deal with commands accommodation are described in [17, 18-24]. We have adopted Ramsis's recommendation that this space should be adapted to the $99^{\text {th }}$ percentile participants, but the position and angles of feet and lower legs for different percentile men are inaccurate, as shown in Figure 4. The figure shows that large men with long lower and upper legs and a sitting height raise their toes and slightly thrust their heel forward so as to lower the seat. This point is changeable along the axis, though not as expected, but considerably smaller and in the opposite the direction were obtained in $\mathrm{Fi}-$ gure 4 . So, we can take it as a fixed point, though in practice it is not.

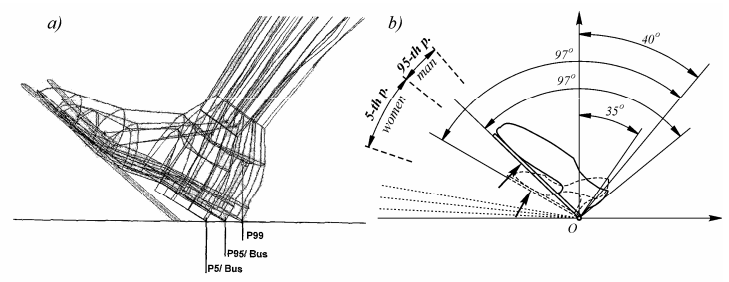

Figure 4 - Heel point of the Ramsis types [5] 
The foot of the $5^{\text {th }}$ percentile woman and the $95^{\text {th }}$ percentile man will have a position similar to that shown in Figure 4. Such an approach and fixed "0" point enable separate construction of the two spaces: a larger one for the seating of a driver with adjustable seat and likely adjustable steering wheel, and the other for the accommodation of fixed foot controls for the 5th percentile woman and also for the seating of at least the 95th percentile man.

As women, have almost identical hip width to those of men, based on the corresponding percentiles, but higher joint mobility, these two factors will alleviate higher non-adjustability of the right leg angle joint when the accelerator pedal is used. The angle has a higher value because of the fixed pedals, and the legs of the 5th percentile woman are shorter, therefore from the common axis of symmetry and the seat that is nearer to the xy plane, the leg is raised at a higher-value angle than the leg of the higher percentile in the population. The dimensions of space for foot controls are given in Figure 5.

The position of foot and space for foot controls accommodation should be located in way that the hip, knee and ankle joint in one plane are parallel projections of the $\mathrm{xz}$ plane, so that there is no horizontal decomposition of the magnitude of force we are exerting on the brake, which, according to [25], should not in any way be more than $420 \mathrm{~N}$.

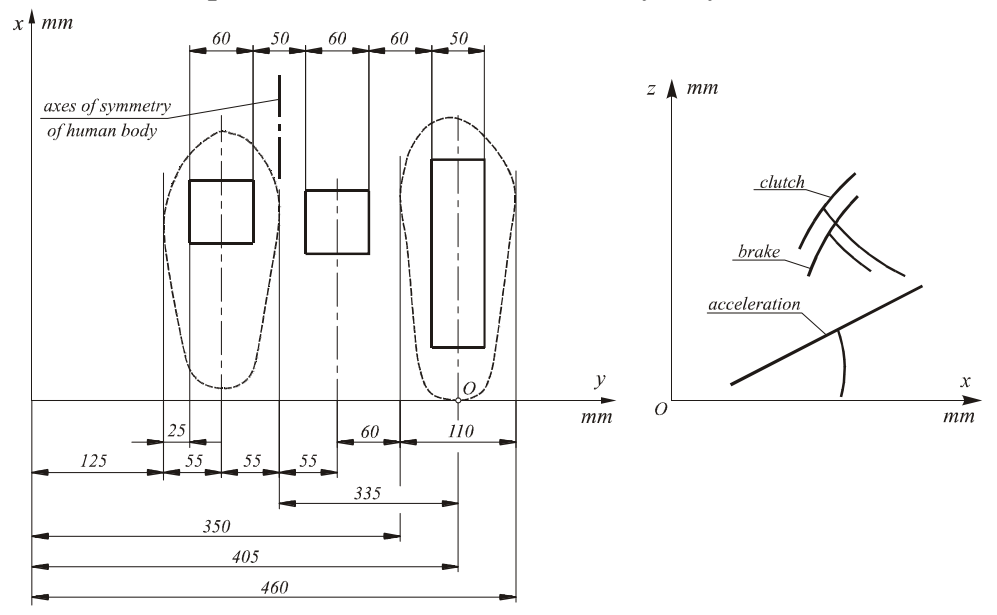

Figure 5 - Position of foot control for Serbian population [5]

Figure 6 shows a cross-section of the space for accommodation of foot controls and the foot of the $5^{\text {th }}$ percentile woman and $95^{\text {th }}$ percentile man, while only the foot length has greater range from 5 th percentile women to $99^{\text {th }}$ percentile men. It is evident that the part of the space for the foot, from the " 0 " point in a forward direction at an angle of $30^{\circ}$ is jointly determined by the $5^{\text {th }}$ percentile woman who increases that space. However, the surface with $B_{2}$ space would be determined by the $95^{\text {th }}$ percentile man.

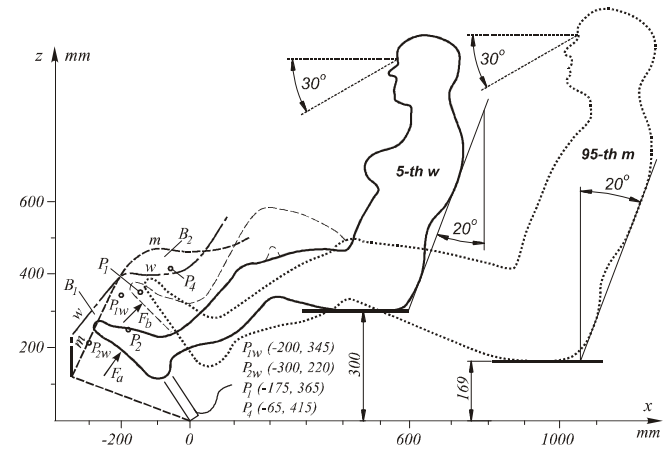

Figure 6 - Optimal passenger car interior space for foot controls accommodation [5]
A large man has thus determined the dimensions of this space with arcs passing through points $\mathrm{P}_{1}$ and $\mathrm{P}_{2}$ and where the lower boundary of the lower position of the accelerator pedal is the direction passing through point $0(0,0)$ and point $P_{2}(-285,105)$. The upper point is the shoe tip at $\mathrm{P}_{4}(-65,415)$ designating the position of the leg maximally raised to operate the clutch pedal. With the supplement for the 99th percentile male foot and the one for shoe sole in the $\mathrm{xz}$ plane we obtain the surface bounded by the $\mathrm{dx}$-axis, a straight line $0-\mathrm{P}_{2}$, the straight line passing with the point along $\mathrm{P}_{2}(-330,115)$ creating an angle of $61^{\circ}$ with the $\mathrm{x}$-axis, while the height along the $\mathrm{z}$-axis is determined by the straight line $\mathrm{z}=465 \mathrm{~mm}$. When operating the brake and the clutch pedals, the points and arcs which determine the space for foot control accommodation and movement of foot and leg are $\mathrm{P}_{1 \mathrm{w}}$ $(-200,345)$ and $P_{3 w}(-300,220)$.

Thus, we locate the various anthropomeasures percentile with limitation angle between anthropomeasures and interior space dimensions. We start sizing from the "0" point, up to head height and vehicle ceiling respectively, which is for the $95^{\text {th }}$ percentile man at $1250 \mathrm{~mm}$ from the vehicle floor. 


\section{INTERIOR SPACE IN Z-Y PLANE FOR THE DRIVER'S KNEES}

A majority of the factors and limitations from the aspect of anthropometry, which we have already considered in determining the space for foot commands [5], have a great effect on optimizing this space factors such as foot width, the correlation between measures of small and large lower and upper legs, sitting height and particularly the new factor of hip width, and their mechanical relation and functions within the mechanism of anthropomeasures of humans. it is also very important to determine the space for the driver's knees in a passenger vehicle.

According to $[6,14]$ the positions on the xy horizontal plane, have the following values on the $\mathrm{z}$ axis 0, 305, 610, 915, 1067 and $1219 \mathrm{~mm}$. Therefore, we are interested in the planes at the height z: 305-305 $\mathrm{mm}$ and $610 \mathrm{~mm}$ for the knees space, and at other planes for the movement when operating the clutch and brake pedals. The angle for knee movement is, according to $[6,14]$ in the xy plane when the lower leg and the sitting height form a $90^{\circ}$ angle, from the hip outwards $33^{\circ}$ for 5 th percentile men, $53^{\circ}$ in average, and $73^{\circ}$ for the 95 th percentile flexibility, and inwa$\operatorname{rds} 11^{\circ}, 31^{\circ}$ and $53^{\circ}$ retrospectively.

Figure 7 shows that in all three versions we have the same lower leg length from the middle of ankle joint $\mathrm{S}$ to the middle of knee $\mathrm{K}$, plus the upper-leg height from the middle of knee $\mathrm{K}$ to the middle of hip $\mathrm{H}$. it was presumed that the vehicle height is the same from floor to ceiling, and that sitting height, and consequently seat height, varies. Horizontal projection of the distance between the middle of joint $S$ to the middle of hip $\mathrm{H}$ on the $\mathrm{x}$ axis is the same, but it is possible to increase that distance until point $\mathrm{H}^{\prime}$. In the first version [I], we have average sitting height and different upper-arm and lower-leg length, and there is no position with an optimal angle of knee joint $\left(84^{\circ}\right.$, $91^{\circ}, 92^{\circ}$ i $90^{\circ}$ ) which is optimal from $95^{\circ}$ to $152^{\circ}$ [11]. For the shortest lower leg, the angle $\beta$ is $13^{\circ}$, which is borderline large, whereas the angle of hip joint and torso orientation can assume an optimal position [11].

For the same correlation between lower and upper leg, with a shorter dimension of sitting height, we have, for the same visual angle (eye level), a raised seat and therefore a satisfactory angle between the seat and the upper leg $\beta$ and a more optimal angle of knee joint in version number II. In the third part of Fig. 7, we can see that a large dimension of sitting height demands a low seat, and for the same leg lengths, knee pole positions in points 1,2, 3 and 4 with a highly inadequate angle of knee joint and angle of hip joint, and also an inadequate $\beta$ angle. The solution is to draw the seat by the center of a rotation of hip H'.

Then for point 4' the angle of knee joint is $126^{\circ}$ and $130^{\circ}$ for point $1^{\prime}$, which is optimal, the angle $\beta$ is significantly reduced $\beta_{4}<\beta_{4} ; 15^{\circ}<23^{\circ} ; \beta_{1}<\beta_{1}$; $24^{\circ}<50^{\circ}$.
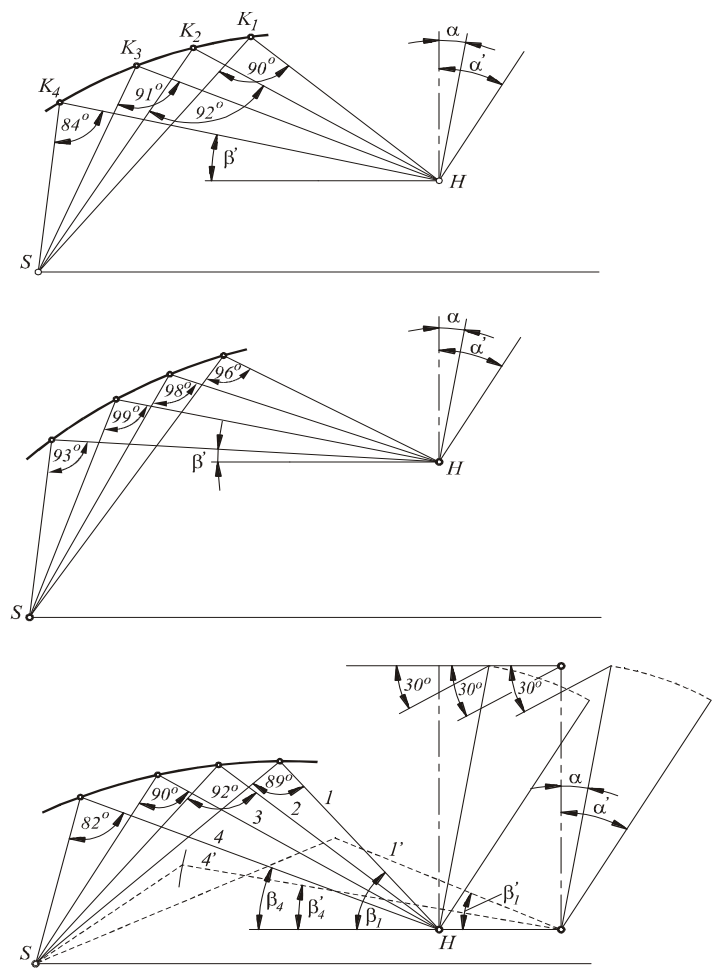

Figure 7 - Positions of anthropomeasures of a driver [6]

Specifically the design space for foot commands and foot movements requires the involvement of measures and foot movements in its sizing. The most important point from the point of moving feet in the use of foot controls half the rotation with the ankle, which allows complex movements of rotation of the foot about center of its rotation and the rotation of the that center about a fixed point on the heel of the vehicle driver ("0" point), as can be seen in Figure 8.

Also we can see that the driver's fingertips greater height as the seat lower and farther away, while the angle between the real OS and the horizontal lower. This angle limited by the possible mobility of the ankle of man, and for 50th percentile men is 73 degrees.

The figure 8 shows that the families of ellipses for the same leg length give angle of knee joint in certain narrow boundaries, in figure 8 from $82^{\circ}$ to $99^{\circ}$, which is another limitation in constructing the interior space of a passenger vehicle. 


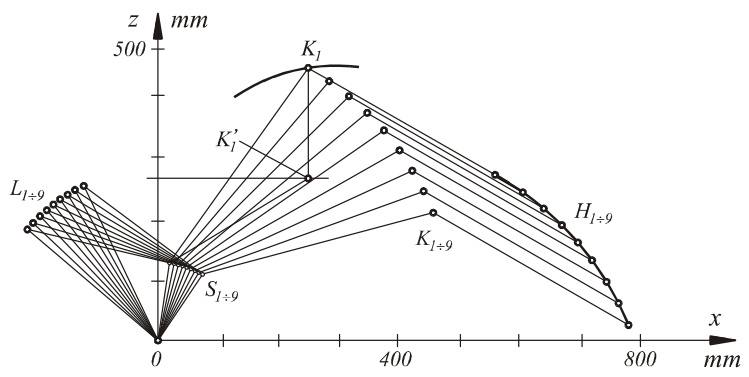

Figure 8 - Limits for approximately the same leg lengths with different upper and lower legs [6]

The distance between points $\mathrm{O}$ and $\mathrm{S}$ for the 50th percentile man for various anthropometric area ranges from 130 to $140 \mathrm{~mm}$. Center of rotation movement of the knee is now adjusted by a half rotation of the ankle. For different dimensions of the foot, calf and thigh, and for the same length legs the problem is simplified if the calculation is done for only the long range of foot.

Mathematical and mechanical calculation can be simplified using the model for all three planes, which was obtained as a projection of certain anthropometric and multiplied by the cosine of the corresponding angle, as shown in Figure 9.

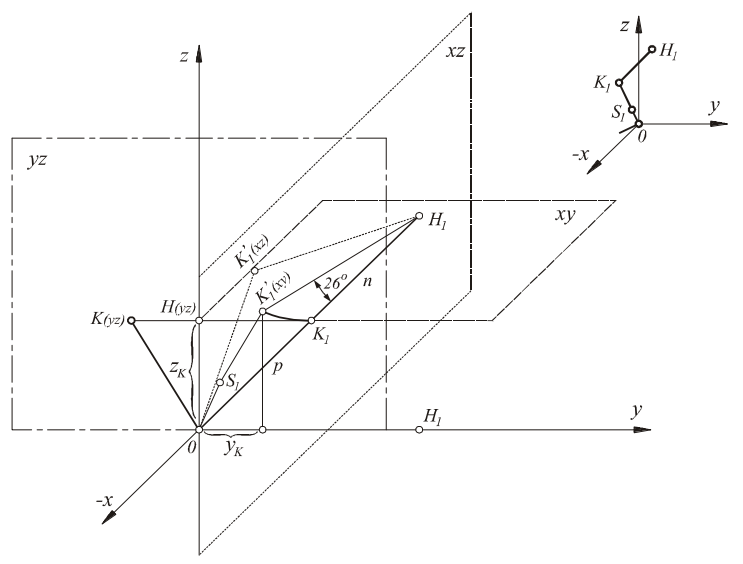

Figure 9 - Position of knee and hip pole point [6]

The upper leg angle for the lowest sitting position $\mathrm{H}_{9}$ and the knee in position $\mathrm{K}_{1}$ is $26^{\circ}$, and the increase of space along the y-axis is around $160 \mathrm{~mm}$ for each knee, i.e. $320 \mathrm{~mm}$, which in driving conditions do not have to be used simultaneously, as it can be seen on Fig. 10.

The upper legs have the same measures, but for the position of $\mathrm{H}_{1}-\mathrm{K}_{1}$, however, in real driving conditions the lower legs cannot be horizontal, and they are not only horizontally contracted from the straight line which passes from $\mathrm{K}_{9}$ to the straight line which passes through $\mathrm{S}_{9}$ axis, but in all planes, so that if it is parallel to the $\mathrm{x}$ plane its contraction along the $\mathrm{x}$ axis multiplied by the cosine of the pertaining angle, and from the position of $\mathrm{K}_{9}$ makes the distance of axis $K_{9}$ and $S_{9}$ in the xy plane in the figure. For the position of $\mathrm{K}_{1}$ this contraction is much greater and it makes the distance from axis $K_{1}$ to axis $S_{1}$.

From data collected in $2009 \mathrm{~s}$ and conclude that there is no such correlation between measures of shoulder width and hip width, which means that these measures equally effect the criteria of what percentile of the population is to be included into the "man passenger vehicle" system.

The width of the seat in a passenger vehicle along the we can calculate y axis dictated by hips can be determined only according to the width of hips of a male driver, because women in Serbia have $20.67 \mathrm{~mm}$ narrower hips. Hip width and sitting height are not correlated, and the coefficient of regression is $r=-$ 0.071 . It can also be seen that the smaller widths are more accurate and more precise, while the larger ones have a large span.

If another $50 \mathrm{~mm}$ is allowed on each side for a horizontal movement, then the space for accommodating a seat should have the width of $650 \mathrm{~mm}$. On the other hand, a seat moves in height along the entire height of seat adjustment of 169-300 mm. Shoulder width is $550 \mathrm{~mm}$ maximum for a $95^{\text {th }}$ percentile man in the 2009 sample, so according to [9] maximum width of space for accommodating a driver at elbow height should be $700 \mathrm{~mm}$.

The largest width of space for accommodating a driver is at the lowest seat level of $169 \mathrm{~mm}$ for the largest drivers, and is calculated on the basis of Figure 10. We can see that a driver with the largest leg length can bend his legs sideways in the knees by approximately one half of an average angle of upperleg movement from hip $\left(26^{\circ}\right)$ and thus lean the upper leg against the sea. The space width of $926 \mathrm{~mm}$ is occasionally required for the driver's spread knees, which places the knee in a position in front of the gear shifter in typical floor operation.

The space dimensions in figure 12 show that an upper-leg length of $600 \mathrm{~mm}$ from the middle of $\mathrm{H}$ is determined by means of the measured length of the $99^{\text {th }}$ percentile man of $748.68 \mathrm{~mm}$ (Table 1) and by excluding only 3 drivers, or $0.37 \%$, from the system according to extremes (shaded area in figure 10b). The distance between the backrest of a seat and a center of hip $\mathrm{H}$ rotation according to [3] is $152.4 \mathrm{~mm}$ for a $1834 \mathrm{~mm}$-tall man, so that measure is 748.68 $152.4=596.28 \mathrm{~mm}$. Since the $99^{\text {th }}$ percentile man in Serbia is $1980.3 \mathrm{~mm}$ tall, we can increase this measure somewhat and say that it is approximately 600 $\mathrm{mm}$. 


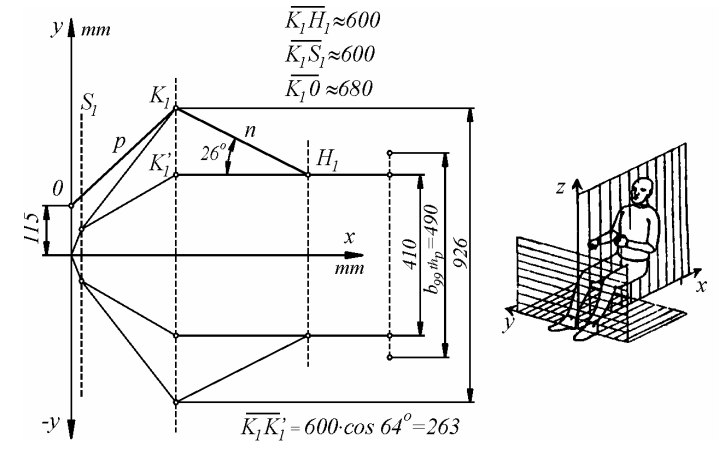

Figure 10 - Width of leg room to accommodate large drivers with knees apart

\section{CONCLUSION}

This paper shows that passenger vehicles are still insufficiently adapted to man and gives certain solutions of that problem. The study proves that the "driver-passenger car" system design requires the coordinate system with the origin at the " $O$ " point located at the contact between floor line and shoe heel of the driver, and that determination of the space and its proportion is governed by an algorithm as defined by the laws of mechanics underlying the functional association with the mechanism of anthropomeasures. Thus, by limiting angles created between anthropomeasures and interior space dimensions we accommodate various dimensions of anthropomeasures, which are not necessarily expressed in percentiles as is the case in almost every study of this optimization. Vehicle dimensions are defined starting from the " $O$ " point to the head height and vehicle ceiling respectively, which is at $1250 \mathrm{~mm}$ height for the very large anthropomeasures of a man. Seat travel along the horizontal line is $460 \mathrm{~mm}$, and along the vertical line starting from floor line from $169 \mathrm{~mm}$ for the largest men to $300 \mathrm{~mm}$ for the smallest women included in the system. The space for foot controls accommodation and their operation is located horizontally along the $x$-axis from the " $O$ " point forwards at $320 \mathrm{~mm}$ and vertically along the $z$-axis at $230 \mathrm{~mm}$. Space height along the $z$ axis amounts to $465 \mathrm{~mm}$. The height of the space along the y-axis is determined by leg anthropomeasures of the $99^{\text {th }}$ percentile man. Since there are different pairs of correlated anthropomeasures of foot length, lower and upper leg, where certain measures are shorter or longer for the same leg length, the design would be more precise if the percentiles of the considered anthropomeasures are calculated according to extreme pairs, such as very small lower leg and long upper leg and other combinations of anthropomeasures.

In that way we could improve the system. The largest space width for accommodating a driver along the $y$-axis is the width occupied by the spread knees of the extremely large lower and upper legs of a driver and it amounts to $926 \mathrm{~mm}$. the next largest width along the $y$-axis is elbow width while operating the steering wheel, also with extremely long arms of male driver (which is a less important limitation since the arm is very flexible). Hip width is not a limitation for space width by itself but only combined with the lower and upper-leg length.

\section{ACKNOWLEDGEMENT}

The paper is supported by a grant from the Serbian Ministry of Science under contracts TR 35017 and $\mathrm{E} ! 6761$.

\section{REFERENCES}

[1] Regulation on the Safety of machinery, "Official Gazette of RS“, No. 13/2010, 2010.

[2] Klarin, M., Cvijanović, J., and Spasojević Brkić, V. Additional adjustment of the driver seat in accordance with the results of the latest antropometric measurements of drivers in Belgrade. Proc. IMechE, Part D: J. Automobile Engineering, 2001, 215(6), 709-712.

[3] Roebuck, J. A. and Kroemer, K. H, E. Engineering antropometry methods, 1975 (John Willey, New York)

[4] Klarin M. M. and Cvijanović J. M. The optimization of the interior of the passenger car, Int. J. of Vehicle Design, Vol. 19, No. 4, pp. 448-453,1998.

[5] Klarin, M. M., Spasojević - Brkić K. V., Sajfert, D. Z., Žunjić, G. A., and Nikolić, S. M., Determination of passenger car interior space for foot controls accommodation, Procs. IMechE Vol. 223 Part D: J. Automobile Engineering, No D 12, pp 1529-1547, 2009.

[6] Klarin, M. M., Spasojević-Brkić, V. K., Sajfert, Z. D., Djordjević, D. B., Nikolić, M. S., \& Ćoćkalo, D. Z. (2011). Determining the width of the optimal space needed to accommodate the drivers of passenger vehicles using the analogy of anthropometric measurement dynamics and mechanical mechanisms. Proceedings of the Institution of Mechanical Engineers, Part D: Journal of Automobile Engineering, 225(4), 425-440.

[7] ISO 4130:1978 Road vehicles-three-dimensional reference system and fiducial marks - definitions, 1978 (International Organization for Standardization, Geneva).

[8] Morgan, C., Chapanis, A., Cook, J., and Lund, M. Human engineering guide to equipment design, 1963 (McGraw-Hill, New York).

[9] Porter J. M. and Porter C. S. Turning automotive design ,inside-out“, Int. J. of Vehicle Design, Vol. 19, No. 4, 1998., 384-401. 
[10] Hamza, K., et al. Combined maximization of interior comfort and frontal crashworting ih preliminary vehicle design, Int. J. Vehicle Design, Vol. 35, No. 3, 2004.

[11] Vogt, C., Mergl, C., and Bubb, H. Interior design layot design with RAMSIS. Human Factors Ergonomics MFG, 2005, 15(2), 197-212.

[12] Demic, M. and Milovanović, M. Elements vehicle design. Report, Faculty of Mechanical Engineering, University of Kragujevac, Kragujevac, Serbia, 1994.

[13] Koelich, M. Automobile seat comfort: occupant preferences vs. anthropometric accommodation. Appl. Ergonomics, 2003, 34, 177-184.

[14] McCormick, E. J. Human factors engineering, 1971 (McGraw-Hill, New York).

[15] TRANS/WP.29/GRSRP/2002/12 Ergonomic Commission for Europe, Inland Transport Committee, World Forum for Harmonization of Vehicle Regulations (WP.29), Working Party on Passive Safety (GRSP), 2002.

[16] Klarin, M., Spasojević Brkić, V., Stanojević, P., and Sajfert, Z. Anthropometrical limitations in the construction of passenger vehicles: case study. Proc. ImechE, Part D: J. Automobile Engineering, 2008, 222(8), 1409-1419.

[17] Borner, C. J., Hoormann, H. J., Rizw, H.G.,Huher, G., Kraus, W., Bigalke, S., Helbig, K., and Kurchmeister, G. Driver's workplace in motor ciaches.
In 91 st session, 17-20 October 2006. informal document GRSG-91-3 (Working Party on General safety Provisions United Nations, Ergonomic Commission for Europe, Geneva).

[18] Kumar A., Bhaskar G., Singj J. K. Assessment of controls layout of Indian tractors, Applied Ergonomics No.40, 2009.

[19] Galer Flyte M. G., Perchard M. The prediction of car driver size and position to enhance safety in crashes, Ergonomics Vol. 42. No.9,.1999.

[20] Pheasant, S. T., Anthropometric estimates for Britich civilian adults, Ergonomics, Vol. 25, No. 11, pp 993-1001, 1982.

[21] Mattew, B. P., Mattew P. R., Optimizing Vehicle Occupant Packaging, Society of Automotive Engineers, 2006-01-0961.

[22] Vasu, M', Mital, A., Evaluation of the validity of anthropometric design assumptions, Int. J. Industrial Ergonomics, 26, p. 19-37, 2000.

[23] Chaffin, B. D., Engineering Anthropometry and Occupational Biomechanics, Salvendy, G., Handbook of Industrial Engineering, John Wiley and Sons, New York - Toronto - Singapore, 1982.

[24] Kinghorn, A. R., Alvah, C., Bittmer, Jr., Truck driver anthropometric date; Estimation of the current population, Int. J. of Industrial Ergonomics 15, 1995, 199-204.

[25]Luczak, H. Arbeits-wissenschaft, 1998 (SpringerVerlag, Berlin)

\section{REZIME}

\section{PROJEKTOVANJE UNUTRAŠNJEG PROSTORA PUTNIČKOG VOZILA}

U radu je dat pregled naših prethodnih istraživanja uz dodatna unapređenja, tako da je dokazana hipoteza da putničko vozilo još uvek nije ergonomski prilagođeno čoveku u dovoljnoj meri, posebno u delu unutrašnjeg prostora za smeštaj i upotrebu nožnih komandi. U ergonomskom prilagođavanju putničkog vozila najznačajnija su tehnička i antropometrijska ograničenja. Pri samom istraživanju je u najvećoj meri korišćena metodologija operacionih istraživanja, tako da su ciljevi opisani funkcijom cilja, dok se sistem „čovek-vozilo“ optimizira uz postojanje ograničenja. U savremenim zaoštrenim ekonomskim i ekološkim zahtevima održivog razvoja u ovom radu je ostvaren cilj konstrukcije unutrašnjeg prostora standardnog putničkog vozila sa optimalnom čeonom površinom i koeficijentom otpora vazduha. Data je originalna metodologija za određivanje unutrašnjeg prostora putničkog vozila. Činjenica da postoji „, “ tačka kao ishodište koordinatnog sistema sa x, y i z osom sistema čovek - vozilo, koja se može smatrati približno fiksnom, omogućila je tačnije određivanje mehaničkih i matematičkih zavisnosti u ovom sistemu. U radu je dokazano da antropomere po dužini imaju mehaničke $i$ matematičke funkcije koje određuju i širinu, odnosno sve tri dimenzije prostora. Data je i konstrukcija za prostor iza vetrobranskog stakla, položaj volana, prostor i položaj nožnih komandi, kao i ukupnog prostora za vozača. Dokazano je da na visinu od poda do krova vozila najveći uticaj imaju antropomere visine sedenja i potkolenice, dok na širinu antropomere potkolenice i natkolenice, a tek onda širina ramena, tako je unutrašnji prostor za vozače putničkog vozila određen visinom $1.250 \mathrm{~mm}$ i širinom za raširena kolena na nivo sedišta $926 \mathrm{~mm}$.

Ključne reči: putničko vozilo, vozač, optimalni unutrašnji prostor 